\title{
Annals of Glaciology 52(57)
}

Sea ice in the physical and biogeochemical system. Part 2 


\section{VOLUME 52 ISSUE $57 \quad 2011$}

\section{EDITORS}

IGS Chief Editor

Jo Jacka

Issue Chief Editor

Mats Granskog

Scientific Editors

Stephen Ackley
lan Allison
Jody Deming
Hajo Eicken
Rolf Gradinger
Stephen Hudson
Nick Hughes
Jennifer Hutchings
Stefan Kern
Pat Langhorne

Andy Mahoney

Thorsten Markus

Rob Massom

Marcel Nicolaus

Christina Pedersen

Kunio Shirasawa

Lars Henrik Smedsrud

Matthew Sturm

Jean-Louis Tison

Timo Vihma

\section{INTERNATIONAL GLACIOLOGICAL SOCIETY}

$\begin{array}{ll}\text { President } & \text { Eric Brun } \\ \text { Vice-Presidents } & \begin{array}{l}\text { Martin Funk } \\ \text { Kumiko Goto-Azuma } \\ \text { Christina Hulbe }\end{array} \\ \text { Treasurer } & \text { lan Willis } \\ \text { Secretary General } & \text { Magnús Már Magnússon }\end{array}$

\section{IN-HOUSE PRODUCTION}

Production Manager

Production Assistant

Reference Editor

House Editor

Publishing Assistant

Typesetter/Programmer
Christine Butler

Craig Baxter

Rowena Baxter

Ken Moxham

Ann Leeding

Sukie Hunter

Cover illustration Underside of sea ice in Fram Strait. Photo by Sebastian Gerland, Norwegian Polar Institute, Norway. 


\section{Annals of Glaciology}

Sea ice in the physical and biogeochemical system. Part 2

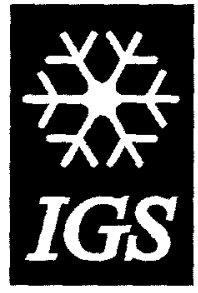

Published by the International Glaciological Society Cambridge, UK 
The Annals of Glaciology is a thematic journal published by the IGS 3-4 times a year. All papers are peer-reviewed and edited.

The accurary of references in the text and lists is the responsibility of the authors, to whom queries should be addressed.

The Annals of Glaciology is available online. Subscribers wishing to access the online journal should go to www.ingentaselect.com/register.htm and follow the online instructions. For subscription information contact igsoc@igsoc.org.

ISSN 0260-3055

ISSN 1727-5644 (Online)

(C) International Glaciological Society 2011

All rights reserved; no part of this publication may be reproduced, stored or retrieved in any form or by any means, electronic, mechanical, photocopying, recording, or otherwise without the prior written permission of the International Glaciological Society (IGS), except as stated below.

The Annals of Glaciology is registered with the Publishers Licensing Society Limited. Consent is given for single copies of single articles to be made for private study or research, or for the personal or internal use of specific clients, provided the appropriate fee is paid to The Copyright Licensing Agency, 90 Tottenham Court Road, London, W1P OLP (Fax: 020-7631. 5555; e-mail: info@cla.co.uk). Illustrations and short extracts from the text of individual contributions may be made provided the source is acknowledged and permission is granted by the authors and the IGS. The IGS hereby gives permission for abstracts of articles in this issue to be reprinted by abstracting journals.

Printed in England by Page Bros (Norwich) Ltd 


\section{PREFACE}

The papers in this issue of the Annals of Glaciology cover the broad topic of sea ice in the physical and biogeochemical system.

The publication was supported by the Research Council of Norway, the Centre for Ice, Climate and Ecosystems (ICE) at the Norwegian Polar Institute, the University of Tromsø and the Climate and Cryosphere Project of the World Climate Research Programme. Altogether 43 papers were accepted for publication after peer review to the normal standards of the Society. I was assisted by a number of Scientific Editors, covering the wide spectrum of papers submitted to the volume: I am most grateful to Stephen Ackley, lan Allison, Jody Deming, Hajo Eicken, Rolf Gradinger, Stephen Hudson, Nick Hughes, Jennifer Hutchings, Stefan Kern, Pat Langhorne, Andy Mahoney, Thorsten Markus, Rob Massom, Marcel Nicolaus, Christina Pedersen, Kunio Shirasawa, Lars Henrik Smedsrud, Matthew Sturm, Jean-Louis Tison and Timo Vihma. Their expertise and efforts are reflected in the breadth and quality of the papers published in this issue.

The publication of a thematic issue on sea ice is as timely as ever. The record low summer sea-ice extent in the Arctic over the past few years has been the subject of much media attention. Many papers in this volume will in turn advance and contribute to our understanding of the processes that are controlling these ongoing changes.

Mats Granskog 


\section{CONTENTS}

\section{Part 2}

Takenobu Toyota, Shuji Ono, Kohei Cho, Kay l. Ohshima

Anja Rösel, Lars Kaleschke

D.K. Perovich, K.F. Jones, B. Light, H. Eicken, T. Markus, J. Stroeve, R. Lindsay

Rosemary Willatt, Seymour Laxon, Katharine Giles, Robert Cullen, Christian Haas, Veit Helm

Sara De La Rosa, Sönke Maus, Stefan Kern

Tim Papakyriakou, Lisa Miller

B.P. Weissling, S.F. Ackley

Susann Müller, Anssi V. Vähätalo, Mats A. Granskog, Riitta Autio, Hermanni Kaartokallio

Thorsten Markus, Robert Massom, Anthony Worby, Victoria Lytle, Nathan Kurtz, Ted Maksym

Motoyo Itoh, Jun Inoue, Koji Shimada, Sarah Zimmermann, Takashi Kikuchi, Jennifer Hutchings, Fiona McLaughlin, Eddy Carmack

Sanja Forsström, Sebastian Gerland, Christina A. Pedersen

Katherine C. Leonard, Ted Maksym

Stefan Kern, Burcu Ozsoy-Cicek, Sascha Willmes, Marcel Nicolaus, Christian Haas, Stephen Ackley

Stefan Kern, Stefano Aliani
Retrieval of sea-ice thickness distribution in the Sea of Okhotsk from ALOS/PALSAR backscatter data

Comparison of different retrieval techniques for melt ponds on Arctic sea ice from Landsat and MODIS satellite data

Solar partitioning in a changing Arctic sea-ice cover

Ku-band radar penetration into snow cover on Arctic sea ice using airborne data

Thermodynamic investigation of an evolving grease to pancake ice field

Springtime $\mathrm{CO}_{2}$ exchange over seasonal sea ice in the Canadian Arctic Archipelago

Antarctic sea-ice altimetry: scale and resolution effects on derived ice thickness distribution

Behaviour of dissolved organic matter during formation of natural and artificially grown Baltic Sea ice

Freeboard, snow depth and sea-ice roughness in East Antarctica from in situ and multiple satellite data

Acceleration of sea-ice melting due to transmission of solar radiation through ponded ice area in the Arctic Ocean: results of in situ observations from icebreakers in 2006 and 2007

Thickness and density of snow-covered sea ice and hydrostatic equilibrium assumption from in situ measurements in Fram Strait, the Barents Sea and the Svalbard coast

The importance of wind-blown snow redistribution to snow accumulation on Bellingshausen Sea ice

An intercomparison between AMSR-E snow-depth and satellite C- and Ku-band radar backscatter data for Antarctic sea ice

A comparison between polynya area and associated ice production with mooring-based measurements of temperature, salinity and currents in the southwestern Ross Sea, Antarctica 
Sönke Maus, Susann Müller, Juliane Büttner, Sabina Brütsch,

Thomas Huthwelker,

Margit Schwikowski, Frieder Enzmann,

Anssi Vähätolo

Thomas Hollands, Wolfgang Dierking

Burcu Ozsoy-Cicek, Stephen F. Ackley, Anthony Worby, Hongjie Xie, Jan Lieser

Ahmet E. Tekeli, Stefan Kern, Stephen F. Ackley, Burcu Ozsoy-Cicek, Hongjie Xie

Olivier Lecomte, Thierry Fichefet, Martin Vancoppenolle,

Marcel Nicolaus

Sharon B. Sneed, Paul A. Mayewski, Daniel A. Dixon

Donald K. Perovich, Jacqueline A. Richter-Menge, Kathleen F. Jones, Bonnie Light, Bruce C. Elder, Christopher Polashenski, Daniel Laroche, Thorsten Markus, Ronald Lindsay

Jennifer K. Hutchings, Andrew Roberts, Cathleen A. Geiger, Jacqueline Richter-Menge

Sebastian Gerland, Christian Haas
Ion fractionation in young sea ice from Kongsfjorden, Svalbard

Performance of a multiscale correlation algorithm for the estimation of sea-ice drift from SAR images: initial results

Antarctic sea-ice extents and concentrations: comparison of satellite and ship measurements from International Polar Year cruises

Summer Antarctic sea ice as seen by ASAR and AMSR-E and observed during two IPY field cruises: a case study

A new snow thermodynamic scheme for large-scale sea-ice models

An emerging technique: multi-ice-core multi-parameter correlations with Antarctic sea-ice extent

Arctic sea-ice melt in 2008 and the role of solar heating 